This item was submitted to Loughborough's Research Repository by the author.

Items in Figshare are protected by copyright, with all rights reserved, unless otherwise indicated.

\title{
Undermining anarchy: Facebook's influence on anarchist principles of organisation in Occupy Wall Street
}

PLEASE CITE THE PUBLISHED VERSION

http://dx.doi.org/10.1080/01972243.2017.1318195

\section{PUBLISHER}

(C) Taylor \& Francis (Routledge)

\section{VERSION}

AM (Accepted Manuscript)

\section{PUBLISHER STATEMENT}

This work is made available according to the conditions of the Creative Commons Attribution-NonCommercialNoDerivatives 4.0 International (CC BY-NC-ND 4.0) licence. Full details of this licence are available at: https://creativecommons.org/licenses/by-nc-nd/4.0/

\section{LICENCE}

CC BY-NC-ND 4.0

\section{REPOSITORY RECORD}

Swann, Thomas, and E. Husted. 2019. "Undermining Anarchy: Facebook's Influence on Anarchist Principles of Organisation in Occupy Wall Street”. figshare. https://hdl.handle.net/2134/24648. 


\title{
Undermining Anarchy: Facebook’s Influence on Anarchist
}

\section{Principles of Organisation in Occupy Wall Street}

\begin{abstract}
This paper contributes to debates around the political potential of social media by examining Occupy Wall Street and activist's use of Facebook. Drawing on concepts rooted in cybernetics and anarchist political theory, the paper argues that the shift in Occupy Wall Street from being a physical protest camp in late 2011 to an online movement in 2012 coincided with a shift in social media activity. On the one hand, analysis of Facebook activity suggests a move from functional to anatomical hierarchy; on the other, it points towards a move from many-to-many communication to one-to-many communication. In conclusion, we argue that this development has served to undermine the movement's anarchist principles of organisation.
\end{abstract}

\section{Introduction}

Much has been written about the role of social media in social movements. Particularly since the rise of the "new global revolutions" that took place in 2011 and after (Mason 2012), scholars have debated the relationship between activist practices and social media platforms such as Facebook and Twitter. Despite the recent emergence of more critical accounts (e.g., Agre 2002; Fuchs 2014; Jarrett 2008; Lovink 2011; Morozov 2011; Poell et al. 2015; Srinivasan 2014), a commonly held view is that social media provides social movements with unique opportunities for reinforcing their democratic credentials, since both are based on non-hierarchical and participatory practices and structures. As Castells (2012, 229) argues, social media allows leaderless movements to "survive, deliberate, coordinate and expand.” 
In this paper, we aim to bring an anarchist perspective to the analysis of the transition of Occupy Wall Street (OWS) from a physical protest camp to an online movement. Drawing on a description of OWS's organisational form, our argument is based on anarchist political theory and, more specifically, the concepts of "functional hierarchy" and "many-to-many communication.” This allows us to develop an understanding of how OWS shifted from largely participatory practices to predominantly centralised ones. This shift, we argue, took place following the eviction of the OWS camp, at which point the OWS Facebook page became the central focus for activists. Highlighting this change in the organisational and communication dynamics of OWS suggests that the potential in mainstream social media platforms for nonhierarchical and even anarchist organising that some authors have proclaimed (e.g., Bruns 2008; Castells 2012; Hardt and Negri 2011) may be a mischaracterisation that fails to take into account how Facebook restricts the activities of users and undermines any radical potential. Here, we hope to be able to provide an answer to the question of whether (and in what ways) Facebook and social media in general are suited to sustaining anarchist principles of organisation. Ultimately, we argue that the shift in OWS from physical camp to online movement signalled a corresponding move from participatory and democratic engagement to an organisational form less reflective of these anarchist organisational principles.

First, we provide a brief overview of non-hierarchical and anarchist organisational practices, how a meeting of anarchism and cybernetics can help shine light on these organisational practices and, finally, the potential in social media for facilitating these practices. Following this, we introduce the case study of OWS, describing how it came to exist primarily as an online movement clustered around the OWS Facebook page. Focusing on a comparison of "likes," “shares," and “comments” on more than 1,400 posts on the Facebook page in three periods, our discussion points towards the shift of the organisational and communication dynamics of OWS 
and will be characterised as a move from participatory practices, on the one hand, to centralised practices, on the other. The analysis presented here, while limited in scope and in need of elaboration in further research, thus aims to provide a contribution to discussions of the communicative and organisational form of social media-backed political movements. This goes beyond a focus on communication or organisation in isolation from one another and, as Bennett and Segerberg (2012) have called for, sees communication and organisation as intimately linked and requiring analysis on that basis.

\section{Anarchism, Organisation, Communication, and Social Media}

\subsection{Anarchist Organisation}

Anarchism emerged as a concrete political movement in the middle of the nineteenth century. While there are numerous earlier examples of movements that have in one way or another opposed economic exploitation, political domination, and religious servitude, it was with the work of Pierre-Joseph Proudhon that a specifically anarchist politics was developed. Proudhon claimed the derogatory term "anarchy”, usually synonymous with chaos, as an expression of liberty achieved not through violence or manipulation but through democratic participation, writing that "society finds its highest perfection in the union of order with anarchy" (1840, n.p.). Subsequent anarchists, such as Michael Bakunin, Louise Michel, Peter Kropotkin, and Emma Goldman, to name but a very few in a rich tradition, developed the politics of anarchism in different ways. At its core, however, was a commitment to individual and collective freedom from domination and exploitation. As Kinna $(2005,1)$ puts it, "anarchism is a doctrine that aims at the liberation of peoples from political domination and economic exploitation by the encouragement of direct or non-governmental action.” How this was realised in practice led to various "schools" of anarchism, such as individualist, collectivist, syndicalist, and even Christian anarchism (ibid.). Indeed, it is more appropriate to speak of “anarchisms”, plural, than 
“anarchism”, singular, given the variety of theories and forms of practice that can be connected to the broad anarchist tradition (Franks 2006). Despite notable periods of revolutionary activity, such as during the Spanish civil war, anarchism was largely eclipsed on the left by the statesocialist Marxists in the twentieth century, and in many cases (including revolutionary Spain and the early Soviet Union) anarchists were repressed as much by those on the left as by the state, capitalism, and the church.

In recent years, however, there has been something of a resurgence in anarchist politics. From uprisings such as the Zapatistas in Mexico to the alter-globalisation movement and more recently in the revolutionary movement in Rojava, the anarchist commitment to achieving order through democratic participation and to individual and collective freedom has come to play a central role in radical politics (Epstein 2001; Gordon 2008; Graeber 2002; Maeckelbergh 2009). Anarchistic forms of organisation have in many ways come to be definitive of contemporary radical social movements. In practice, the anarchism of movements such as the Indignados in Spain and Occupy in the US and elsewhere has been manifest in a number of ways. Chief among them is the insistence on radically participatory and democratic forms of decisionmaking and the importance of prefiguration. As Graeber (2012) notes, OWS, the specific case study we focus on here, involved decision-making by consensus, a practice developed in the feminism of the 1970s and in Quaker communities, and an attempt to prefigure relationships of non-domination and non-exploitation in the here and now. While Marxist politics has often been characterised as aiming to bring about a democratic and participatory society through the use of a centralised authoritarian state, many anarchists focus on realising the goals of their politics immediately (Franks 2003). For the anarchism that is influential in contemporary social movements, the avoidance of domination and exploitation is something to be practiced now rather than postponed until an unspecified time in the future. It is, therefore, a participatory form of democratic decision-making, often involving consensus rather than majority voting, and a 
prefigurative perspective on social change that is central to the anarchism of contemporary radical politics. This is not to say that anarchism has become detached from its roots in the labour struggles that were at the heart of social movements in the nineteenth century. Rather, anarchism is distinctive in so far as it demands that struggles of labour and against intersecting forms of oppression are conducted in democratic and participatory ways that prefigure the kinds of relationships anarchists value (and as opposed to more centralised and top-down iterations of these struggles).

As we have noted, anarchism has featured in several accounts of OWS and other recent movements and uprisings (e.g., Bray 2013; Gibson 2013; Hammond 2015; Taylor 2013; van de Sande 2013). As Franks notes (2006, 196-200), historical examples of anarchist organisation can in fact be quite distinct from one another, ranging from workplace organisation to social movement organisation and affinity groups, on the one hand, and from highly participatory to highly centralised organisational structures, on the other. It is the more radically decentralised forms of anarchist organisation, however, that are more in tune with the core anarchist principles of autonomy and self-organisation. Indeed, it is these principles that are relevant to how we discuss OWS and that are important to how anarchism is currently practiced by a large section of both the anarchist movement and the radical left more generally. While there are important differences between alternative strands of anarchism, the organisational practices that anarchism has influenced in OWS and other contemporary movements are based on an "anarchist common sense" and a "basic libertarian impulse" (Wilson 2014, 8-13). This impulse is to reject domination and exploitation and to try and build relationships and organisational structures that facilitate non-domination and non-exploitation. It is through networked and federated organisational structures that this is to be achieved. Networks suggest ways in which complex processes can be organised without the need for centralised control (Juris 2009; Moglen 1999), while federated structures can be seen as formalising this networking logic by determining 
different layers of organisation, making possible coherent decision-making processes that retain the radically democratic and participatory nature of anarchist politics (Graham 2011; Ward 1973).

\subsection{Functional Hierarchy}

The account of anarchist organisation as a set of practices that prioritise a networked or federated structure can be elaborated in greater detail by looking not only further into classical and contemporary anarchist theory and practice but into another tradition entirely. Cybernetics emerged during the Second World War as an attempt at unifying various scientific disciplines around the ideas of feedback and flows of information. Norbert Wiener, who coined the term, defined it as the science of "control and communication in the animal and the machine" (Wiener 1961 [1948]) and it focused on identifying how feedback processes and the information networks they rely on play a role in regulating systems. When applied to social sciences and questions of organisation, later cyberneticians identified the idea of self-regulation with more explicitly political accounts of self-organisation. Here, regulation occurs not through automatic processes but by people actively using information to collectively alter their behaviour (see Duda 2013). Cyberneticians such as Stafford Beer (1967) noted the importance of the idea of networks to systems of self-regulation and self-organisation, highlighting the ability for decentralised organisational structures to better respond to complex and changing environments. Indeed, it is this focus on self-organisation that provides the bridge between anarchism and cybernetics. One of the concepts at work in cybernetics that is of relevance to the account of OWS we provide here and to anarchist politics more generally is that of "functional hierarchy."

While it might seem odd to entertain a notion of hierarchy in a discussion aimed at articulating an anarchist form of organisation, the concept of functional hierarchy plays on a crucial 
distinction made by cyberneticians such as Beer (1994 [1979]), Allena Leonard (2009; 2013), and Gordon Pask (1968) that was picked up on by anarchist writer John D. McEwan. McEwan turned to cybernetics in trying to add detail to the anarchist account of self-organisation in an article he wrote for the journal Anarchy in 1963. Functional hierarchy is counterpoised by cyberneticians to anatomical hierarchy. The latter, they argue, is reflected in what is typically understood as an organisational hierarchy; that is, multiple levels with a chain of command such that each level is subordinate to the levels above it and where the top level has overall control over decision-making in the organisation. It is this model of organisation that comes to mind when one thinks of corporations, political parties, and the military, and it is this that anarchists are opposed to in so far as it embodies domination and exploitation. For example, Bookchin (1982, 4) describes this form of hierarchy as “a complex system of command and obedience in which elites enjoy varying degrees of control over their subordinates.” Functional hierarchy, on the other hand, involves distinct orders of decision-making such that lower-order decisions are subject to parameters set by higher-order decisions (i.e., higher-order decisions are decisions about lower-order decisions). Certain decisions may be considered to be higher or lower order than others while there are no bodies or individuals that are higher or lower than others. As McEwan $(1963,44)$ puts it, framing functional hierarchy in cybernetic terms and in relation to the notion that organisations sit in complex and changing environments, "some parts [of the organisation] may deal directly with the environment, while other parts relate to activity of these first parts.” This hierarchy, then, is not a structural or anatomical hierarchy in which certain individuals or groups have fixed roles but a functional one of levels of decision-making.

What is crucial to this understanding of functional hierarchy is the recognition that while there may or may not be an anatomical, structural hierarchy in an organisation, there will always be a hierarchy of roles or functions whereby some actions and decisions depend on "higher" levels of action and decision-making. McEwan points out that while the organisational structures that 
anarchist are opposed to solidify these roles in fixed levels, anarchist organisation allows people to shift between roles as situations demand. ${ }^{1}$ For the kinds of anarchist organisation described above, this suggests how different levels of decision-making can operate. On the one hand, individual activists and small collectives have the autonomy to make decisions themselves, while on the other, decisions with a broader scope that set the conditions for smaller-scale decisions are made at larger meetings and general assemblies that involve more activists. What a non-hierarchical structure allows is for members of an organisation to shift between lower and higher functional roles without these roles becoming fixed in an anatomical hierarchy with leaders and followers. This mirrors the federated form of organisation mentioned briefly above.

Leadership provides a useful example that can help illustrate what functional hierarchy means in practice. Recent work that has tried to set out an anarchist account of leadership has turned on the distinction between leadership and leaders. While leaders are individuals in positions of authority with the ability to issue commands and an expectation that those commands will be carried out, leadership can instead be understood as a function that may be required at certain moments but that is not necessarily fixed as a position with decision-making privilege at all times. Through mechanisms such as rotating leadership roles and distributing skills and knowledge, anarchist groups are able to include functionally distinct levels of decision-making (that would otherwise be characterised by the leader-follower structural relationship) in such a way that leadership is constructed as a "function and effect" (Sutherland et al. 2013, 16). Sutherland et al. (ibid., 17) write that "although individuals may take on more of an active leadership role in certain situations, elsewhere, they would step back as others would take the lead” (see Western 2014 for an alternative take on leadership in anarchist organisation). This

\footnotetext{
$1 \quad$ It should be noted that the focus on eliminating anatomical hierarchies tends to overlook many people's lacking will to power, or to put it differently, people’s desire for representation (for instance, see Laclau's (2005, 83-117) discussion of the relationship between representation and affect). For a similar argument made in relation to social media, see Gerbaudo’s (2015) account of “populism 2.0.” Taking an anarchist perspective, Bookchin, for example, suggests that such a lack of a will to self-organisation is connected to an internalisation of a subjectivity of hierarchy (e.g, 1982, 63).
} 
counters Gerbaudo’s (2012, 43-44) claim that leadership roles in anarchist movements still coalesce around specific individuals who act as choreographers rather than as leaders. From an anarchist perspective, despite Gerbaudo's claims to the contrary, leaders-as-choreographers would still centralise decision-making privilege in a potentially restricted elite. A functional hierarchy perspective, on the other hand, allows for leadership functions without even the limited form of fixed leader positions that Gerbaudo suggests.

Rather than this idea of functional hierarchy posing a challenge to the anarchist rejection of centralisation and domination, it highlights the fact that anarchists may be opposed not to a hierarchy of functions or tasks but to a hierarchy of structure, position, and decision-making privilege. Crucially, it also points towards a definition of anarchism that focuses less on hierarchy in all its forms and more on domination and how it may be realised in some forms of hierarchy (i.e., anatomical, structural) and potentially negated by others (i.e., functional) (see Kinna and Prichard [forthcoming] on anarchism and non-domination). Indeed, the connections drawn here between anarchism and cybernetics have been covered elsewhere, and despite the problems they may throw up there is reason to take them seriously (in addition to McEwan, see also de Geus 2014; Dolgoff 1977; Duda 2013). Ward (1966, n.p.) similarly highlighted the importance of cybernetics, noting that "cybernetic theory with its emphasis on self-organising systems, and speculation about the ultimate social effects of automation, leads in a similar revolutionary direction” as anarchism. For cyberneticians like Beer and for anarchists, the key to self-organisation is the autonomy that the different parts of an organisation are able to enjoy (see Espinosa et al. 2004; 2008). It is here that the connection between anarchism and cybernetics is strongest. Both build on the idea of self-organisation and the role of autonomy therein and both explore how principles like these can be realised in specific forms of organisation. 
In addition to the distinction between functional and structural hierarchy, there is one other concept that we want to draw on in elaborating on an anarchist account of organisation and how it relates to OWS. Again, this takes inspiration from cybernetics and Wiener's claim that an understanding of any system involves not only identifying self-organising processes but also communication dynamics. Indeed, for cybernetics, organisation and communication are essentially the same process. This is of course also central to the idea of networked organisation. The mode of communication that we want to suggest is best-placed to further elucidate the anarchistic practices at work in OWS is "many-to-many communication.”

Jurgen Ruesch first used the term “many-to-many communication” in the late 1950s in reference to the different modes of human communication in groups, the others being one-to-many and many-to-one (1957, 158; see also Ruesch and Bateson 1968, 39-40). More generally, the notion of group communication that mirrors the idea of a conversation among equals has figured in cybernetics in the work of Pask (see Pickering 2010, 322-332, 364-371). Recent scholarship that defines many-to-many communication does so in answer to the question "who gets to say something to how many?”, and in relation to technological mediation as well as the form itself (based on Jensen and Helles 2011, 519-520; see also McQuail 2010, 144): Many-to-many communication refers to the communication that takes place in networks where everyone participating is able to send and receive information to and from everyone else in the network. The technological mediation of many-to-many communication would include wikis, blogs, social network sites, online chatrooms and, potentially, micro-blogging sites.

The concept has been applied to the communication practices of radical left groups and the associated uses of social media platforms (REDACTED REFERENCE 2; see also CostanzaChock 2006). Linking it to prefiguration and democratic and participatory organisation, we propose that many-to-many communication be considered a necessary, rather than sufficient, condition for the anarchist types of organisation that we discuss in relation to OWS. For a 
particular organisational form to reflect the participatory nature of anarchist organisation, the communication practices engaged in ought to be many-to-many, as this will allow for all involved to be able to share and receive information and to be involved in discussions around decision-making. Many-to-many communication, we suggest, is essentially participatory and so should play a role in anarchist organisation.

Of course, arguing that such organisational forms should embody many-to-many communication is not to suggest that this is enough in order for these forms to operate in a democratic way. Even if everyone involved is able to speak and participate in decision-making, it does not mean that everyone's voice will carry equal weight, and there remain opportunities for asymmetrical power relationships to skew the organisation in the direction of more authoritarian forms (e.g., Freeman 1970). Furthermore, we recognise that the specific organisational forms of protests such as Occupy are flexible and complex and change over time and in different locations. The organisational structures we highlight here - functional hierarchy and many-to-many communication - are intended as very broad characterisations within which different more specific organisational forms may operate. Nonetheless, we stress that these two concepts can help to characterise some of the necessary elements of non-hierarchical, democratic, and participatory organisation, and it is along these lines that we conduct our analysis of OWS and the use of Facebook.

\subsection{Social Media}

Due to the many-to-many potentials of social media platforms such as Facebook and Twitter, several scholars have argued that it converges with the participatory and democratic ideals of social movements such as OWS. What has been characterised as the "architecture of participation” of social media (O’Reilly 2005; Deuze 2006) is taken to highlight the leaderless 
structures and practices of participation and collaboration that, for many people, define social media. For example, Hardt and Negri $(2011,2)$ write that "they correspond in some sense to the horizontal network structures and democratic experiments of the movements themselves." Similarly, Castells $(2012,229)$ argues that social media technology "creates conditions for a form of shared practices that allows leaderless movements to survive, deliberate, coordinate and expand.” At work, here is an account of the social aspects of social media that focus not only on communication but also on how platforms allow people to organise (for relevant definitions of social media, see Lovink 2011; Fuchs and Sandoval 2014). While authors such as those already mentioned highlight the possibility of social media supporting social movements (see also Juris 2008; 2012; Mason 2012; Stiegler 2009), there are others who have presented more complex accounts of the relationship between social media (and the Internet in general) and the democratic and participatory aspects of social movements (see Fuchs 2014; Jarrett 2008; Morozov 2011; Terranova 2000). (For an overview of these debates, see Fenton and Barassi 2011; Markham 2014).

Our aim here is to examine how social media - Facebook in particular - operated at two stages in the OWS movement: during the existence of the camp in Zuccotti Park and later, after the camp's eviction when the movement shifted to a predominantly online form. We argue that this shift signalled a parallel move from OWS as a participatory and democratic engagement to an organisational form less reflective of the anarchist organisational ideals described above. Crucially, as OWS became more of an online, Facebook-based movement, both the functional hierarchy and many-to-many communication that are central to a cybernetic understanding of self-organisation were eclipsed by both a structural or anatomical hierarchy, on the one hand, and a one(or few)-to-many communication dynamic, on the other. Importantly, our focus is not 
on the content of either the organisational or communicative structures ${ }^{2}$ but on the nature of those structures themselves. Based on an empirical analysis that draws on OWS participants' reactions to posts on the movement's Facebook page, we suggest that social media presents possibilities for constraining participation and democracy as much (if not more) than they do for enabling them. The more OWS existed as an online movement and less as a physical protest camp, the more it is apparent that the architecture of Facebook, far from being an "architecture of participation”, is in fact an architecture of hierarchy. Hence, through the forthcoming analysis, we raise and attempt to answer the question of whether Facebook is able to sustain anarchist organisational forms.

\section{Empirical Framework and Data Collection}

\subsection{The Case of Occupy Wall Street}

In mid-July 2011, half a year into the so-called Arab Spring, Canadian activist group Adbusters issued a call for "redeemers, rebels and radicals" to occupy Wall Street in a protest against the corporate take-over of politics. “Are you ready for a Tahrir moment?”, they asked (Adbusters, 2011). On 17 September, thousands responded by pouring into Zuccotti Park in Lower Manhattan. In the park, protesters managed to create their own microcosm of democracy by prefiguring the society they advocated. All decision-making processes were based on active participation and democratic deliberation and no decisions were made at general assemblies until either consensus or "modified consensus” (90\% majority) had been reached (Kang 2013). Furthermore, an advanced system of hand-signals and the so-called "Human Mic" (Radovac 2014) were used to ensure that everyone was heard during large meetings. In this way, the movement was firmly rooted in autonomy, democratic structures, and highly participatory

$2 \quad$ For example, Bennet and Segerberg (2012) highlight the personal narratives at work in the messages that were communicated in Occupy and other protests, while Coretti and Pica (2015) examine the role of communication in constructing collective identity. 
practices. This has led a series of scholars to argue that OWS was, in fact, based on anarchist principles of organisation (e.g., Bray 2013; Graeber 2012; Hammond 2015; Taylor 2013). As Gibson (2013, 346) explains:

The rise of Occupy has given hope that a new society is possible based on opposition to hierarchy and on principles of direct democracy, liberty and equality, and that such a society is immanent within existing society. The struggle for emancipation through an anarchical politics holds the promise of developing a different understanding of the social world and new prospects for its reorganisation.

The occupation of Zuccotti Park lasted almost two months until the protesters were evicted by the then Mayor of New York City, Michael Bloomberg, on 15 November (Graeber 2013). OWS did not, however, dissolve completely. Throughout what remained of 2011 and into 2012, the movement continued to stage demonstrations and occupations around New York City, but as time went on, sections of OWS slowly became focused online and centred around a Facebook page with approximately half a million users. The general assembly was thus abandoned as the centre of the movement and substituted by the technological infrastructure of Facebook. How that affected the movement's anarchist-inspired principles of organisation and communication is what this paper sets out to explore.

\subsection{Data Collection}

To investigate OWS's transition from a physical protest camp to an online movement, we employ a summative content analysis that focuses less on the specific meaning of various elements and more on their usage (Hsieh and Shannon 2005, 1283). This approach allows one to aggregate chosen elements of a certain dataset and to compare their frequency. In the analysis 
presented here, we focus on the frequency of "likes," "shares," and "comments" on the posts made by the administrators of the OWS Facebook page. ${ }^{3}$ This research was initially carried out by the second author (REDACTED REFERENCE 1). The approach taken here mirrors that of Coretti and Pica (2015) in so far as it examines the activity of Facebook users. However, while their research focuses on the content of posts and comments, the research discussed here looks at the form of the Facebook activity, bracketing for the time being the actual content of what users and administrators were posting and commenting. As such, this study is purely quantitative and does not involve a qualitative analysis of Facebook activity.

In the previous research, it was argued that the shift from offline to online meant that the deliberation and participation that was central to the offline version of OWS gave way to "a logic of amplification, where the sole purpose of the movement's participants is no longer to deliberate about politics” (REDACTED REFERENCE 1, following van Dijck 2009). Instead, activists "became increasingly affirmative towards content distributed top-down by the movement's administrators” (REDACTED REFERENCE 1), acting as transmitters rather than co-creators of this content. Importantly, this change was attributed in part to how Facebook facilitates certain kinds of social interaction over others. This ties in with how Beverungen et al. (2015) have characterised the role that Facebook plays in "managing” online activity and how Coretti and Pica (2015) have described Facebook’s protocols as encouraging “vertical patterns of communication” (ibid., 962) that skewer interaction towards centralisation and hierarchy.

Here, we build on the earlier research by re-reading the same data through the concepts discussed above as well as relating these findings to broader questions of anarchist organisation. Before proceeding, it must be noted that there are methodological nuances associated with comparing the frequency of likes, shares, and comments. Each operates differently and while

3 Until early 2015, the Facebook API only displayed the "value" of shares if the number was more than ten. Even though this generally constitutes a problem for quantitative studies of user activity on Facebook (Rieder et al. 2015), this is not the case with the present study, as all recorded posts received far more than ten shares. 
likes and shares require relatively little effort (a press of a button), commenting is more timeconsuming and perhaps indicates greater commitment. On top of this, likes and shares connote different relationships to content, with likes suggesting a certain level of sympathy or approval and shares suggesting more commitment and a greater sense of adding one’s voice to amplifying a message. Perhaps unsurprisingly, for the three time frames during which the frequency of likes, shares, and comments were recorded, likes were by far the most frequent, with shares playing less of a role and comments less still. Nonetheless, comparing the frequencies of the three, taken as proxies for measuring participation, can still reveal something about the organisational dynamics of OWS and how this changed from one period to the next. The three periods during which the frequency of likes, shares, and comments were recorded were: 20 September to 20 November 2011; 20 March to 20 May 2012; and 20 September to 20 November 2012. Thus, the empirical domain of the analysis encompasses one period during the occupation of Zuccotti Park and two periods following the eviction of the park, after which the movement coalesced primarily around the Facebook page, which at the time of writing has 814,411 likes. $^{4}$

The research was conducted by manually counting the number of likes, shares, and comments on the 20 most active posts (i.e., those with the highest number of likes, shares, and comments) in each of these three timeslots. The intention was to aggregate the reactions of Facebook users on the OWS Facebook page. Central to the analysis is how the frequency of these reactions changed over time. The diagram below (Figure 1) charts the development of these frequencies over the whole time period of the study, from 20 September 2011 to 20 November 2012. To assist in the comparison, the frequencies here are displayed as percentages of the total. The aim

$4 \quad$ The number of users liking the page has naturally changed since 2011. For instance, in the autumn of 2012, “only” 411,776 users liked the page. This paper’s argument thus comes with the caveat that the changing composition of the "user population" could have had an influence on the varying levels of engagement. 
of the diagram is thus not to tally the overall number of, for example, likes but to compare the frequencies of the three practices. ${ }^{5}$

\section{INSERT FIGURE 1 HERE}

However, for the sake of clarity, the absolute numbers of likes, shares, and comments are displayed in the table below (Figure 2). Aside from providing an overview of the overall total of the three kinds of activities, the table likewise illustrates the development of the overall activity as such. Here, it is particularly interesting that the level of user activity on OWS' Facebook page did not decrease over the three periods. In fact, quite the opposite seems to be the case. For instance, the autumn of 2012 witnessed almost twice as much overall activity as the spring of 2012. This preliminary finding ties in with van Dijck's (2009) argument that a lack of userdriven content creation does not necessarily signal a lack of participation on the part of the users. Instead, it implies another kind of participation; one that is less active, and in the case of OWS, more affirmative.

\section{INSERT FIGURE 2 HERE}

\section{Analysis}

The tendency indicated by this mapping exercise is clear (see Figure 1). The steady decrease of likes and comments correlates negatively with a steady increase in shares. In the autumn of 2011, likes made up 76\% of responses to posts by OWS Facebook page administrators (84,900 likes). In spring 2012, this had decreased to 66\% (55,287 likes), and by autumn 2012 there was a decrease again to 52\% (76,992 likes). Across the same periods, shares increased from $14 \%$ of

$5 \quad$ Crucially, this expands on the methodological perspective taken by Bennett and Segerberg (2012), who do not properly differentiate between commenting and sharing within their "connective action" framework. It should be noted that Bennett and Segerberg's analysis is aimed at narrative and expression rather than organisational structure, and this may well suggest alternative methodological scopes. 
user activity in autumn 2011 (15,850 shares) to 29\% in spring 2012 (24,101 shares) and 45\% in autumn 2012 (67,395 shares). Thus, those users interacting with the posts of the OWS page administrators shift between autumn 2011 and autumn 2012 from predominantly liking posts (and sharing them at a much lower rate) to liking and sharing at roughly the same rates. By autumn 2012, user activity on the Facebook page was almost evenly split between liking and sharing. In contrast, across the three periods examined, there were far fewer comments, owing perhaps, as mentioned above, to the time-consuming nature of commenting in comparison to liking and sharing. Despite this, there is still an observable decline in users commenting on posts on the OWS page. In autumn 2011, commenting made up around $10 \%$ of user activity $(10,698$ comments). By spring 2012, there is a decrease to 5\% (4,257 comments), and by autumn 2012 this had dropped to 3\% (4,327 comments). Evidently, the actual numbers in this case reinforce this dramatic reduction in the level of engagement in the Facebook page's audience. In the first period examined, there were on average 535 comments per post, while in the last period this number fell to only $216 .^{6}$

This shift can be understood as a transformation from the co-creation of ideas and active debate that initially characterised OWS to a more top-down transmission of the page administrators' messages. As OWS was transformed from a movement rooted in the physical space of Zuccotti Park, with its general assemblies and direct democratic discussion and decision-making reinforced by a social media presence, to a purely online movement, it became, we argue, markedly less participatory and horizontal. In what remains of this paper, we analyse and discuss this change in the nature of user activity on the OWS Facebook page through the concepts of functional hierarchy and many-to-many communication. To quickly recap, we suggest that the kinds of participatory and democratic forms of organisation that OWS embodied

$6 \quad$ Interestingly, this contrasts with Coretti and Pica's (2015) analysis of the anti-Berlusconi movement's use of Facebook, which shows a similar decrease in deliberation over a certain time period as is suggested by our analysis but in fact an increase in commenting. We cannot speculate on why this discrepancy occurs, but it could be an issue to be pursued in further research. 
in its early days in Zuccotti Park - which can be characterised as anarchist - are well articulated by the concepts of functional hierarchy and many-to-many communication. Our contention, therefore, is that the shift from an offline, social media-backed movement to an online, social media-focused movement meant a shift from functional to anatomical hierarchy, on the one hand, and from many-to-many to one(or few)-to-many communication, on the other.

\subsection{From Functional Hierarchy to Anatomical Hierarchy}

Across the three time periods of OWS we examine here, the online user activity suggests that OWS ended up (in spring and autumn of 2012) tending towards an anatomical hierarchy. The shift from co-creation of information and messages through deliberation to the amplification of messages created by the Facebook page administrators mirrors an anatomical hierarchy in which higher-level functions (i.e., creating messages) are structurally distinct from lower-level functions (i.e., spreading these messages). The social media-based organisational dynamic of OWS became such that participatory engagement, through commenting, shrank from $10 \%$ to $3 \%$ of overall user activity. At the same time, the activity of simply transmitting these posts, through sharing, grew from $14 \%$ to $45 \%$ of overall activity. Rather than the Facebook page being a space in which a large number of users would participate in forming the discourse of OWS, it became characterised by a structural division of labour between administrators and other users. Looking at this through the lenses of anarchism and cybernetics, therefore, one could argue that while OWS Facebook activity (i.e., the activity of activists on the Facebook page) operated along the lines of a functional hierarchy while the physical camp was in existence, the activity changed to reflect an anatomical hierarchy in which the administrators distributed messages that were transmitted by the users. 
To highlight this dynamic, one can focus on the specific roles of users and administrators at each stage of the movement. In autumn 2011, when the physical camp was the focus of activity, users of the OWS Facebook page acted both as transmitters of official messages from the administrators and as co-creators of those messages. We suggest that this latter aspect is reflected in the higher frequency of commenting, indicating an active engagement on the part of Facebook users in debates on the Facebook page. Crucially, at this stage, this online activity was coupled with the offline activity in the camp itself, which involved general assemblies and other forums for discussion in which the precise message (in terms of principles, grievances, and demands) of OWS was formed. So, while Facebook users who "liked" and were actively engaged in the OWS Facebook page did play a role in amplifying or transmitting the posts of the administrators, the content of those posts was, to an extent, up for democratic debate and was formed through processes of participatory deliberation. At this stage, therefore, the movement was characterised by a functional hierarchy in which activists and Facebook users could, potentially, move from the lower-order function of transmitting messages - through sharing and liking - to the higher-order function of co-creating those messages - through commenting or participating in offline discussions and general assemblies. In spring and autumn 2012, the offline aspect of OWS is gone and the movement shifts to the Facebook page as the main forum for activity. At this point, the role of users is less the higher-order one of co-creation and is increasingly reduced to the lower-order of amplifying and transmitting posts created by the administrators.

Turning to the role of administrators, our analysis suggests that when the OWS camp and the participatory forms of decision-making embodied in the general assemblies still physically existed, the function of the Facebook page administrators involved a greater degree of cocreation than it did in 2012. While administrators would still provide the actual content of Facebook posts, this was the product of debate both offline in the camp and online in the 
comments. In 2012, with the physical camp no longer in existence, the function of the administrators becomes much more about simply creating message content that is posted and amplified by other Facebook users. This acts to reinforce the hierarchical division between administrators and users and, importantly, does so in such a way that the elements of functional hierarchy present in 2011 are increasingly absent in 2012. Instead, the Facebook activity of OWS becomes characterised more by an anatomical hierarchy, in which higher-order functions are fulfilled by an exclusive set of individuals (the administrators) and the lower-order functions are fulfilled by a more numerous but equally fixed set (the users or activists). It is in this way, therefore, that we want to suggest that OWS, in terms of its online presence, Facebook at least, made a shift from a tendency towards functional hierarchy in 2011 to a tendency towards anatomical hierarchy in 2012.

Interestingly, this mirrors how anarchists such as Bookchin have described the emergence of hierarchy in human society. For Bookchin (1982), hierarchy developed in preliterate societies due to the functional division of roles being linked to specific groupings within societies (growing food and cooking with women, hunting and fighting with men, religious roles with more senior members of the society). Over time, this division of labour comes to be institutionalised, and societies move from the kind of social organisation that anarchists champion to those associated with domination and hierarchies of command. For example, Bookchin writes (ibid., 74) that "the roles each individual played began to change from egalitarian relationships into elites based increasingly on systems of obedience and command.” The same can be seen with OWS, where hierarchies of functional roles come to operate as nascent anatomical hierarchies of command. Therefore, as we have suggested, an anarchist response would be to resist the forming of select groups around functional roles, as these groupings can form the initial stages of the anatomical hierarchy that anarchists ought to avoid. 


\subsection{From Many-to-Many Communication to One-to-Many Communication}

In terms of the communication relationships, a similar picture can be presented. Insofar as OWS subscribes to the principles of participation and democracy, one would expect the communication practices both offline in the physical camp and online on OWS's social media presence to be many-to-many in nature. This expectation draws on the concept of prefiguration (e.g., Franks 2003; Maeckelbergh 2009) used to describe the way in which anarchist and radical left activism should aim to realise in the present the long-term goals of the movement and that the means and ends should be consistent. If movements like OWS aim to create participatory and democratic structures of deliberation and decision-making then, the argument goes, these characteristics should be embodied in the means they use.

Elements of prefiguration can be seen in the general assemblies that typified OWS and other Occupy camps, where anyone could speak and be involved in the discussions about the priorities, activities, and overall message of the camp. As previously discussed, a similar shift from functional to anatomical hierarchy can be seen in the online communication practices made possible by the OWS Facebook page. In autumn 2011, the Facebook activity of OWS activists was dominated by sharing and liking but at the same time involved a high frequency of comments. This commenting, we would argue, is reflective of a many-to-many communication practice. All Facebook users are able to reply to posts with comments and thus are able to engage in a discussion around the content of the posts. To the extent that this is an open conversation in which a large number of users can interact with one another, this can be described as many-to-many. The participatory and democratic ideals of OWS and of anarchist organisation are, to some extent, present in the practice of commenting.

Moving to the analysis of Facebook activity in spring and autumn 2012, the frequency of comments decreases (from 10\% of all activity in autumn 2011 to 3\% in autumn 2012). With the 
concomitant increase in shares (from $14 \%$ to $45 \%$ of activity), we argue that OWS' Facebook activity becomes less reflective of many-to-many communication and more reflective of one(or few)-to-many communication in which administrators' posts are broadcast to a group of followers who, instead of engaging in debate focused on the content of these posts, are increasingly inclined to amplify the message. In this case, returning to the definition of many-tomany communication discussed earlier in this paper, a few administrators are able to spread their message to many Facebook users. Rather than being two distinct tendencies, the shift from functional to anatomical hierarchy and the shift from many-to-many communication to one-tomany communication can be understood as part of the same change in the nature of OWS from a site of participation and democracy (in 2011) to one of followership and hierarchy (in 2012). According to this account, these shifts consigned activists and Facebook users to the role of amplifiers or transmitters of messages created and posted by administrators. The hierarchy was cemented as a fixed structure, and the communication practices came increasingly to resemble traditional top-down broadcast formats rather than open conversations.

\subsection{Comparison with the Overall Popularity of OWS}

Comparing the data collected for this research with broader accounts of participation in OWS is difficult. There are no clear and reliable figures for the numbers of participants in the offline general assembly and spokescouncil meetings during and after the existence of the encampment at Zuccotti Park. While these meetings did extend into March of 2012, over four months after the eviction of the original camp, we have found no figures for attendance at the meetings, and there is no record of meetings in the second and third periods that we have examined, so a comparison is impossible. What we can say is that there seems to have been the beginnings of a downturn in activity in February and March of 2012. Up until then (September 2011 to January 
2012), there was a general assembly or a spokescouncil meeting every day. In February 2012, there were 19 such meetings (out of 29 days; 65.5\%) and in March there were 17 (out of 31 days; 54.8\%). However, of course, this does not indicate how many participants were active in these months, and the transcripts and minutes of these meetings (available online at www.nycga.net) do not provide figures for attendance.

Across the three periods examined, there is a significant drop in overall interest in OWS. In the second period, Google searches for the term "occupy wall street" dropped to less than $5 \%$ of their level in first period. In the third period, they fell again to less than $2 \%$ of their first period level. However, this says nothing about participation or even the continued interest among initial participants. It is unsurprising that interest in OWS should wane in general over the course of one year, especially given the initial high level of interest in autumn 2011 (searches in the third period are just over $42 \%$ of the level in the second period, suggesting a slowing of the decline in interest after the first period when the camp featured prominently in the media). Ultimately, then, it is impossible to determine how the change in dynamics of participation we have observed in Facebook activity relates to such dynamics offline. All we can say with confidence is that offline participation did decrease after our first period, as evidenced by the decline in frequency and subsequent cessation by our second period of regular offline meetings.

\section{Concluding Discussion}

Our core argument here is that from its inception in autumn 2011, through the eviction of the camp at Zuccotti Park in New York, and into its existence as a primarily online social movement in 2012, OWS changed. Based on an analysis of the activity on its Facebook page, we have tried to show that participation and democratic engagement in (co-)creating the message that OWS was putting out declined as the movement's activities became increasingly defined by its online 
social media presence. Drawing on a perspective informed by both anarchist organisational practice and anarchist engagements with cybernetics, we have argued that this change can be understood simultaneously as, firstly, a shift from functional hierarchy to anatomical hierarchy and, secondly, a shift from many-to-many communication to one-to-many communication. Taking the frequency of likes, shares, and comments as proxies for measuring different aspects of participation, in both cases, the online activity or function of Facebook users and OWS activists becomes less about participation and more about amplification or transmission of a set message as time goes on. The administrators, in contrast, start out as actors engaged in participatory discussions around the content of Facebook posts and end up, in 2012, in hierarchical positions producing content that is more and more simply transmitted or amplified by users. Thus, we can suggest as one conclusion that OWS' Facebook activity came to reflect not the democratic participation of both a functional understanding of hierarchy and the manyto-many nature of some communication practices, but instead an anatomical or structural hierarchy and a one(or few)-to-many communication dynamic.

On the one hand, this reinforces arguments about how Facebook activity (and mainstream social media activity more generally) in practice departs from the hype around an "architecture of participation” (O’Reilly 2005). Rather than fostering conversational engagement, co-production of content and democratic deliberation, social media platforms like Facebook can be seen to extend or replicate dominant paradigms of communication such as fixed hierarchical divisions between content producers and consumers/transmitters and forms of activity that centre on accepting and amplifying messages rather than contesting or co-creating them (Fuchs 2014). According to this position, it could be argued that the participatory and democratic elements of OWS that were central to the physical camp became less definitive of the movement as it relocated almost entirely online. In other words, a movement that exists on social media solely or primarily will not be able to maintain a participatory and democratic nature as a result of the 
ways in which online activity is managed on platforms like Facebook (Beverungen et al. 2015). As Coretti and Pica $(2015,963)$ put it, in reference to the anti-Berlusconi movement in Italy, “Facebook code increasingly promotes top-down flows of communication, which [...] progressively decreased the plurality of voices within the movement’s page.”

On the other hand, a strong argument could be put forward that the analysis presented here is, firstly, overly charitable to OWS at its height in autumn 2011 and, secondly, that the changes in OWS' online activity are not as pronounced as we have suggested. On the first of these points, one could highlight the centralised control of OWS' social media presence in the early days of the camp as a sign that administrators always held the positions of hierarchical authority that we have suggested only emerged properly in 2012 (e.g., see Gerbaudo 2012). On the second point, criticism could underline the fact that, even in autumn 2011, shares and likes, which we suggest are more indicative of an anatomical hierarchy and one-to-many communication practices, were far more frequent than comments (90\% of all activity compared to $10 \%)$. We have argued that the shift from comments making up 10\% of OWS' Facebook activity in autumn 2011 to 3\% in autumn 2012 signals a qualitatively significant change in the participatory and democratic character of OWS as a movement. In response, it could of course be argued that this represents no significant change and that OWS always involved both functional and anatomical hierarchies and both many-to-many and one-to-many communication practices.

This introduces a nuance that our analysis has thus far not touched on: rather than social movement organisations being wholly definable by one or the other of these dichotomies, it may be more likely that they will always embody elements of both. As Chadwick (2007) notes, social movements exhibit hybrid forms of organisation rather than distinct forms that comply with strict theoretical models. Similarly, Agre (2002) argues that the reality of online communication is far more complex than narratives of participation and democracy, for example, might suggest. Agre also points towards competing accounts of the role of the Internet 
when it comes to politics. Rather than social media such as Facebook introducing elements of structural hierarchy and one-to-many communication, it could be that they in fact reinforce or amplify those elements already present in OWS. Fortunati (2014) has presented a corresponding case for a more nuanced picture of how social media relates to empowerment. Using a terminology that we have avoided here due to its complexity, Fortunati makes the point that both "power over" (the kind of control or domination that anarchists are opposed to) and "power to" (empowerment or the kind of control that sits well with anarchist accounts of selforganisation) can be supported by social media. She writes, "in the case of new media, with their openness and affordances, the possibility of empowerment for users is higher compared to the system of traditional mass media, which was fundamentally closed” (ibid., 180). However, while social media may provide “the utopia of a nonhierarchical space where equal, 'horizontal,' and peer-to-peer relationships are considered possible” (ibid., 175), they can also, as we have shown in our analysis and as Fortunati argues, operate as spaces of domination that reproduce hierarchies of leadership. In stressing this nuance and complexity, the concepts deployed in this paper can be fruitfully applied in describing the organisational dynamics of OWS.

In closing, we want to note one further potential weakness in our analysis. Methodologically, we have here drawn on a quantitative account of the frequency of certain forms of behaviour on OWS' Facebook page. While this has been useful in pointing towards the presence or otherwise of a functional hierarchy and of many-to-many communication practices, it leaves a lot of important questions unanswered. For example, one could question whether the relatively high frequency of commenting in 2011 really does reflect co-creation and not just unproductive noise. In following up this study, we would stress the importance of qualitative research (such as interviews with OWS activists and Facebook users and an analysis of the content of posts and comments) in examining and attempting to articulate the personal and group experiences of participation and hierarchy. In pursuing this further research, we would also suggest the use of 
tools such as IBM Bluemix, which was unavailable to us when conducting data collection and analysis (Bluemix was launched in June 2014, while the data collection was conducted in late 2012) but which could provide for deeper analyses of the dynamics of Facebook activity.

\section{References}

Adbusters. 2011. \#Occupywallstreet: A shift in revolutionary tactics. Retrieved from https://www.adbusters.org/blogs/adbusters-blog/occupywallstreet.html

Agre, P. E. 2002. Real-Time Politics: The Internet and the Political Process. The Information Society 18 (5):311-31.

Ashby, W. R. 1956. An Introduction to Cybernetics. London and New York, NY: Methuen.

Ashby, W. R. 2004 [1962]. Principles of the Self-organizing System. E:CO 6 (1-2):102-26.

Bakunin, M. 1971. On the International Workingmen’s Association and Karl Marx. In Bakunin on Anarchy, ed. S. Dolgoff, 286-307. New York, NY: Vintage Books.

Beer, S. 1967. Cybernetics and Management. Second Edition. London: The English Universities Press.

Beer, S. 1972. Brain of the Firm. London: Allen Lane the Penguin Press.

Beer, S. 1994 [1979]. Heart of the Enterprise. Chichester at al.: John Wiley \& Sons.

Bennett , W. L., and A. Segerberg. 2012. The Logic of Connective Action. Information, Communication \& Society 15 (5):739-68.

Beverungen, A., S. Böhm, and C. Land. 2015. Free Labour, Social Media, Management: Challenging Marxist Organization Studies. Organization Studies 36 (4):473-89.

Bookchin, M. 1982. The Ecology of Freedom. The Emergence and Dissolution of Hierarchy. Palo Alto, CA: Cheshire books. 
Bray, M. 2013. Translating anarchy. The anarchism of Occupy Wall Street. Alresford: Zero Books.

Castells, M. 2012. Networks of outrage and hope: Social movements in the Internet age. Cambridge: Polity Press.

Chadwick, A. 2007. Digital Network Repertoires and Organizational Hybridity. Political Communication 24 (3):283-301.

Coretti, L., and D. Pica. 2015. The Rise and Fall of Collective Identity in Networked Movements: Communication Protocols, Facebook, and the Anti-Berlusconi Protest. Information, Communication \& Society 18 (8):951-67.

Costanza-Chock, S. 2006. "Horizontal communication and social movements. Analytical note for Manuel Castells’ research on communication, power, and counterpower in the Network Society, Los Angeles, 2006.” Retrieved from http://web.mit.edu/schock/www/docs/horizonal\%20communication\%20and\%20social\%20 movements.pdf

de Geus, M. 2014. Peter Kropotkin’s Anarchist Vision of Organization. ephemera: theory \& politics in organization 14 (4):853-71.

Deuze, M. 2006. Participation, Remediation, Bricolage: Considering Principal Components of a Digital Culture. The Information Society 22 (2):63-75.

Dolgoff, S. 1977. The Relevance of Anarchism to Modern Society. Retrieved from http://theanarchistlibrary.org/library/sam-dolgoff-the-relevance-of-anarchism-to-modernsociety

Duda, J. 2013. Cybernetics, Anarchism and Self-organisation. Anarchist Studies 21 (1):52-72. 
Epstein, B. 2001. Anarchism and the Anti-Globalization Movement. Monthly Review 53 (4). Retrieved from http://monthlyreview.org/2001/09/01/anarchism-and-the-antiglobalization-movement/

Espinosa, A., R. Harnden, and J. Walker. 2004. Cybernetics and Participation: From Theory to Practice. Systemic Practice and Action Research 17 (6):573-89.

Espinosa, A., R. Harnden, and J. Walker. 2008. A Complexity Approach to Sustainability Stafford Beer Revisited. European Journal of Operational Research 187:636-51.

Fenton, N., and V. Barassi. 2011. Alternative Media and Social Networking Sites: The Politics of Individuation and Political Participation. The Communication Review 14 (3):179-96.

Fortunati, L. 2014. Media Between Power and Empowerment: Can We Resolve This Dilemma? The Information Society 30:169-83.

Franks, B. 2003. The Direct Action Ethic from 59 Upwards. Anarchist Studies 11 (1):13-41.

Franks, B. 2006. Rebel Alliances. The Means and Ends of Contemporary British Anarchisms. Oakland, CA and Edinburgh: AK Press.

Freeman, J. 1970. The Tyranny of Structurelessness. Retrieved from http://www.jofreeman.com/joreen/tyranny.htm

Fuchs, C. 2014. Social Media. A Critical Introduction. London: Sage.

Fuchs, C., and M. Sandoval. 2014. Introduction. Critique, Social Media and the Information Society in the Age of Capitalist Crisis. In Critique, Social Media and the Information Society, eds. C. Fuchs and M. Sandoval, 1-47. New York, NY and London: Routledge.

Gerbaudo, P. 2012. Tweets and the Streets. Social Media and Contemporary Activism. London: Pluto. 
Gibson, M. R. 2013. The Anarchism of the Occupy Movement. Australian Journal of Political Science 48 (3):335-48.

Gordon, U. 2008. Anarchy Alive. Anti-Authoritarian Politics from Practice to Theory. London and Ann Arbor, MI: Pluto Press.

Graeber, D. 2002. The New Anarchists. New Left Review 13 (January-February):61-73.

Graeber, D. 2012. Occupy Wall Street's Anarchist Roots. In The Occupy Handbook, ed. J. Byrne, 141-49. New York, NY: Back Bay Books.

Graeber, D. 2013. The Democracy Project: A History, a Crisis, a Movement. London: Allen Lane.

Graham, R. 2011. Colin Ward: Anarchy and Organisation. Anarchist Studies 19 (2):84-91.

Hammond, J. L. 2015. The Anarchism of Occupy Wall Street. Science \& Society 79 (2):288313.

Hardt, M., and A. Negri. 2011. The Fight for 'Real Democracy' is at the Heart of Occupy Wall Street. New York. NY: Council on Foreign Relations.

Hsieh, H., and S. E. Shannon. 2005. Three approaches to qualitative content analysis.

Qualitative Health Research 15 (9):1277-88.

REDACTED REFERENCE 1

Jarrett, K. 2008. Interactivity is Evil! A Critical Investigation of Web 2.0. First Monday 13(3). Retrieved from http://firstmonday.org/article/view/2140/1947

Jensen, K. B., and R. Helles. 2011. The Internet as a Cultural Forum: Implications for Research. New Media \& Society 13 (4):517-33.

Juris, J. 2008. Networking Futures. The Movements against Corporate Globalization. Durham, NC and London: Duke University Press. 
Juris, J. 2009. Anarchism, or the cultural logic of networking. In Contemporary anarchist studies. An introductory anthology of anarchy in the academy, eds. R. Amster et al. Oxon: Routledge.

Juris, J. 2012. Reflections on \#Occupy Everything. Social Media, Public Space, and Emerging Logics of Aggregation. American Ethnologist 39 (2):259-79.

Kang, S. 2013. Demands belong to the 99\%? The conflict over demands, issues, and goals in OWS. In Occupying Political Science: The Occupy Wall Street Movement from New York to the World, eds. E. Welty, M. Bolton, M. Nayak, and C. Malone, 59-88. New York: Palgrave Macmillan.

Kinna, R. 2005. Anarchism: A Beginner’s Guide. Oxford: Oneworld.

Kinna, R., and A. Prichard. Forthcoming. Anarchism and Non-Domination.

Land, C., and D. King. 2014. Organizing Otherwise: Translating Anarchism in a Voluntary Sector Organization. ephemera: theory \& politics in organization 14 (4):923-50.

Leonard, A. 2009. The Viable System Model and Its Application to Complex Organizations. Systemic Practice and Action Research 22 (4):223-33.

Leonard, A. 2013. Viable Systems Model Revisited. A Conversation with Dr. Allenna Leonard. Retrieved from http://www.segroup.de/library/public/Interview_Leonard_Viable_System_Model_Revisite d.pdf

Lovink, G. 2011. Networks Without a Cause. A Critique of Social Media. Cambridge and Malden, MA: Polity.

Maeckelbergh, M. 2009. The Will of the Many. How the Alterglobalisation Movement is Changing the Face of Democracy. London and New York, NY: Pluto Press. 
Markham, T. 2014. Social Media, Protest Cultures and Political Subjectivities of the Arab Spring. Media, Culture \& Society 36 (1):89-104.

Mason, P. 2012. Why It's Kicking Off Everywhere. The New Global Revolutions. London and New York, NY: Verso.

McEwan, J. D. 1987 [1963]. Anarchism and the Cybernetics of Self-organising Systems. In A Decade of Anarchy (1961-1970). Selections from the Monthly Journal Anarchy, ed. C. Ward, 42-58. London: Freedom Press.

McQuail, D. 2010. McQuail's Mass Communication Theory. London: Sage.

Medina, E. 2011. Cybernetics Revolutionaries. Technology and Politics in Allende’s Chile. Cambridge, MA: MIT Press.

Moglen, E. 1999. Anarchism triumphant: Free software and the death of copyright. First Monday 4 (8). Retrieved from http://firstmonday.org/ojs/index.php/fm/article/view/684/594

Morozov, E. 2011. The Net Delusion. How Not to Liberate the World. London: Allen Lane.

O'Reilly, T. 2005. What is web 2.0. Retrieved from http://www.oreilly.com/pub/a/web2/archive/what-is-web-20.html

Pask, G. 1968. An Approach to Cybernetics. London: Hutchinson.

Pickering, A. 2010. The Cybernetic Brain. Sketches of another Future. Chicago, IL and London: The University of Chicago Press.

Poell, T., R. Abdulla, B. Rieder, R. Woltering, and L. Zack. 2015. Protest Leadership in the Age of Social Media. Information, Communication \& Society 0 (0):1-21. 
Proudhon, P-J. 1840. What is Property? An Inquiry into the Principle of Right and of

Government. Retrieved from: https://theanarchistlibrary.org/library/pierre-josephproudhon-what-is-property-an-inquiry-into-the-principle-of-right-and-of-governmen

Radovac, L. 2014. Mic Check: Occupy Wall Street and the Space of Audition. Communication and Critical/Cultural Studies 11 (1):34-41.

Rieder, B., R. Abdulla, T. Poell, R. Woltering, and L. Zack. 2015. Data critique and analytical opportunities for very large Facebook pages: Lessons learned from exploring "We are all khaled said.” Big Data \& Society 2 (2):1-22.

Ruesch, J. 1957. Principles of Human Communication. Dialectica 11 (1):154-66.

Ruesch, J., and G. Bateson. 1968. Communication. The Social Matrix of Psychiatry. Second Edition. New York, NY: W. W. Norton \& Company.

Srinivasan, R. 2014. What Tahrir Square Has Done for Social Media: A 2012 Snapshot in the Struggle for Political Power in Egypt. The Information Society 30 (1):71-80.

Seeds for Change 2013. A Consensus Handbook. Retrieved from

http://www.seedsforchange.org.uk/handbookweb.pdf

Starhawk 2011. The Empowerment Manual. A Guide for Collaborative Groups. Gabriola Island: New Society.

Stiegler, B. 2009. Acting Out. Stanford, CA: Stanford University Press.

Sutherland, N., C. Land, and S. Böhm. 2013. Anti-leaders(hip) in Social Movement Organizations: The Case of Autonomous Grassroots Groups. Organization 0 (0):1-23.

\section{REDACTED REFERENCE 2}

Taylor, B. 2013. From alterglobalization to Occupy Wall Street: Neoanarchism and the new spirit of the Left. City 17 (6):729-47. 
Terranova, T. 2000. Free Labour: Producing Culture for the Digital Economy. Social Text 18 (2):33-58.

Van de Sande, M. 2013. The Prefigurative Politics of Tahrir Square-An Alternative Perspective on the 2011 Revolutions. Res Publica 19 (3):223-39.

Van Dijck, J. 2009. Users Like You? Theorizing Agency in User-generated Content. Media, Culture \& Society 31 (1):41-58.

Walter, W. G. 1963. The Development and Significance of Cybernetics. Anarchy 25:75-89. Retrieved from https://archive.org/details/AnarchyNo.25

Ward, C. 1966. Anarchism as a Theory of Organization. Retrieved from http://theanarchistlibrary.org/library/colin-ward-anarchism-as-a-theory-of-organization

Ward, C. 1973. Anarchy in Action. London: George Allen and Unwin Ltd.

Western, S. 2014. Autonomist Leadership in Leaderless Movements: Anarchists Leading the Way. ephemera: theory \& politics in organization 14 (4):673-98.

Wiener, N. 1961 [1948]. Cybernetics; or Control and Communication in the Animal and the Machine. Second Edition. New York, NY and London: MIT Press and John Wiley \& Sons.

Wilson, M. 2014. Rules Without Rulers. The Possibilities and Limits of Anarchism. Alresford: Zero Books. 